\title{
Pengaruh Perasan Umbi Bengkuang (Pachyrhizus erosus L.) terhadap Gambaran Histopatologi Lambung Mencit (Mus musculus L.) dengan Model Tukak Lambung
}

Reza Pertiwi ${ }^{1}$, Hari Marta Saputra ${ }^{2}$

${ }^{1}$ Program Studi S1-Farmasi, Fakultas Matematika dan Ilmu Pengetahuan Alam, Universitas Bengkulu, Bengkulu

${ }^{2}$ Program Studi Biologi, Fakultas Matematika dan Ilmu Pengetahuan Alam, Universitas Bengkulu, Bengkulu

*Corresponding author: rpertiwi@unib.ac.id

\begin{abstract}
Background: Gastric ulcer is a disease caused by disturbances in the upper gastrointestinal tract caused by excessive secretion of acid and pepsin by the gastric mucosa. Gastric ulceration can occur due to excessive consumption of alcohol because it damages the gastric mucosal barrier and causes acute gastritis such as gastrointestinal bleeding. Bengkuang (Pachyrhizus erosus L.) contains flavonoids which is well-known to reduce stomach acid as a curative agent. Objective: To see the effect of bengkuang juice as a preventive agent on mice (Mus musculus L.) induced by gastric ulcer using alcohol. Methods: Giving bengkuang juice orally with doses of 20, 40, and 60\% and sucralfate as a positive control for 12 days. After 1 hour of treatment on the 12th day, mice were given $5 \mathrm{~g} / \mathrm{Kg}$ of ethanol for 24 hours. Results: The results showed that the index values of gastric ulcer in the normal group, negative control, bengkuang juice doses 20, 40, and 60\%, and sucralfate were 0; 3.89; 0.56; $0.22 ; 1.22$ and 1.11 respectively. This is supported by the histopathological depiction of the stomach of the mice which also showed improvement in the stomach of the mouse which was given bengkuang juice. Conclusion: Giving bengkuang juice can reduce the number of ulcers with an improvement in histopathological depiction of mice stomach.
\end{abstract}

Keywords: Pachyrhizus erosus, gastric ulcers, histopathology of gastric

\begin{abstract}
Abstrak
Pendahuluan: Tukak lambung merupakan penyakit akibat gangguan pada saluran gastrointestinal atas yang disebabkan sekresi asam dan pepsin yang berlebihan oleh mukosa lambung. Tukak lambung dapat terjadi karena konsumsi alkohol yang berlebih karena merusak sawar mukosa lambung dan menyebabkan gastritis akut seperti perdarahan saluran cerna. Bengkuang (Pachyrhizus erosus L.) memiliki kandungan flavonoid yang diketahui mampu mengurangi asam lambung sebagai agen kuratif. Tujuan: Melihat pengaruh air perasan bengkuang sebagai agen preventif pada mencit (Mus musculus L.) yang diinduksi tukak lambung dengan menggunakan alkohol. Metode: Memberikan air perasan bengkuang secara peroral dengan dosis 20, 40, dan 60\% dan sukrafat sebagai kontrol positif selama 12 hari. Setelah 1 jam pemberian perlakuan hari ke-12, mencit diberikan etanol sebanyak 5 g/Kg BB selama 24 jam. Hasil: Data hasil pengamatan menunjukkan nilai indeks tukak lambung pada kelompok normal, kontrol negatif, perasan bengkuang dosis 20, 40, dan 60\%, serta sukralfat secara berurutturut yaitu $0 ; 3,89 ; 0,56 ; 0,22 ; 1,22$ dan 1,11 . Hal ini didukung oleh gambaran histopatologi lambung mencit yang juga menunjukkan adanya perbaikan pada lambung tikus yang diberikan air perasan bengkuang. Kesimpulan: Pemberian perasan umbi bengkuang dapat mengurangi jumlah tukak dengan adanya perbaikan gambaran histopatologi lambung mencit.
\end{abstract}

Kata kunci: Pachyrhizus erosus, tukak lambung, histopatologi lambung

\section{PENDAHULUAN}

Bengkuang (Pachyrhizus erosus L.) merupakan tanaman merambat yang telah banyak dibudidayakan terutama untuk memperoleh umbinya (Feri, 2008). Bengkuang diketahui mengandung pachyrhizon, rotenon, vitamin B1, dan vitamin C (Masenchipz, 2008). Bengkuang juga mengandung mineral tinggi seperti fosfor, zat besi, serta kalsium. Pada pengobatan tradisional, bengkuang diketahui dapat menurunkan kadar gula darah pada penderita diabetes (Feri, 2008). 
Bengkuang temasuk dalam famili Fabaceae. Famili Fabaceae banyak dilaporkan mengandung fitoestrogen dan memungkinkan mengandung flavonoid. Bengkuang diduga memiliki sumber antioksidan yang potensial (Lukitaningsih, 2010).

Mentang dkk. (2016) menunjukkan pemberian perasan umbi bengkuang $60 \mathrm{mg}$ selama 10 hari menunjukkan radang lebih sedikit dibandingkan tanpa pemberian perasan umbi bengkuang pada tikus yang diinduksi aspirin. Aspirin dapat menyebabkan tukak lambung. Tukak lambung merupakan penyakit akibat gangguan pada saluran gastrointestinal atas yang disebabkan sekresi asam dan pepsin yang berlebihan oleh mukosa lambung (Avunduk, 2008).

Alkohol diketahui mempunyai efek lokal terhadap lambung. Semakin lama mengkonsumsi alkohol maka semakin banyak sel lambung yang akan mengalami kerusakan (Kumar dkk., 2007; Pan dkk., 2008; Goodman, 2008).

Penelitian sebelumnya yang menggunakan perasan umbi bengkuang lebih banyak menunjukkan efek kuratif, oleh karena itu penelitian ini bertujuan untuk mengetahui aktivitas preventif perasan umbi bengkuang terhadap mencit dengan model tukak lambung.

\section{BAHAN DAN METODE \\ Bahan}

Bahan yang digunakan dalam penelitian ini adalah umbi bengkuang yang telah diidentifikasi di Laboratorium Biologi Fakultas MIPA Universitas Bengkulu, mencit (Palembang Tikus Centre), pakan, ranitidin, $\mathrm{NaCl} 0,9 \%$, etanol absolut, akuades, dan pewarna hematoksilin dan eosin.

\section{Alat}

Alat-alat yang digunakan adalah sebagai berikut: keranjang, beaker glass, pengaduk, kompor, cawan porselin, labu takar, labu ukur, pipet tetes, pipet volume, propipet, gunting, ember, timbangan analitik, rotary evaporator, corong Buchner, labu hisap, kertas saring, waterbath, chamber, mikrotom, oven. Pada perlakuan hewan uji digunakan spuit injeksi volume 3,0 $\mathrm{mL}$ dan 1,0 $\mathrm{mL}$ (Terumo), flakon, pipa kapiler, eppendorf, alat bedah, objek glass dan mikroskop optik digital.

\section{Metode}

Aklimatisasi hewan uji

Sebelum dilakukan perlakuan, hewan uji mencit terlebih dahulu diaklimatisasikan dalam kondisi laboratorium selama satu minggu dengan diberikan makan dan minum yang cukup.

\section{Pembuatan air perasan umbi bengkuang}

Tanaman umbi bengkuang diperoleh dari Pasar Tradisional Panorama. Pengolahan umbi bengkuang untuk menjadi air perasan memerlukan beberapa tahapan. Untuk pertama kalinya kulit umbi bengkuang segar dibuang atau dikupas dan dibersihkan dari kotoran dengan pencucian menggunakan air mengalir, selanjutnya umbi bengkuang diparut. Setelah diperoleh parutan umbi bengkuang, kemudian dibuat air perasan. Air perasan dimasukan ke dalam wadah yang telah disiapkan. Air perasan ini dibuat setiap hari sebelum dilakukan perlakuan.

\section{Hewan percobaan}

Hewan percobaan dibagi menjadi 6 kelompok, masing-masing kelompok terdiri dari 5 ekor hewan uji (mencit). Kelompok I (normal) hanya diberi makan dan minum selama 12 hari, kelompok II (kontrol) diberi makan dan minum selama 12 hari, kelompok III diberi air perasan umbi bengkuang dengan dosis $20 \% \mathrm{~b} / \mathrm{v}$, kelompok IV diberi air perasan dengan dosis $40 \% \mathrm{~b} / \mathrm{v}$, kelompok $\mathrm{V}$ diberi air perasan dengan dosis $60 \% \mathrm{~b} / \mathrm{v}$. Perlakuan kelompok III, IV, dan V diberikan secara per oral selama 12 hari dengan volume pemberian 0,6 mL. Kelompok VI diberikan sukralfat secara peroral selama 12 hari. Setelah satu jam perlakuan pada hari ke-12 diberikan induksi etanol $96 \%$ secara peroral dengan dosis $5 \mathrm{~g} / \mathrm{KgBB}$ kecuali kelompok I. Setelah pemberian induksi etanol hewan di puasakan. Pembedahan hewan dilakukan setelah 24 jam pemberian induksi etanol.

Pengamatan makroskopik pada tukak lambung

Setelah dibedah, dilakukan pengamatan makroskopik lambung untuk dapat mengetahui jumlah dan ukuran lesi/ulkus yang terbentuk pada mukosa lambung. Lambung dibuka dengan dibedah pada lengkung terbesar (kurvatura mayor) dan dibersihkan dengan larutan $\mathrm{NaCl}$ 0,9\% lalu dibentangkan pada permukaan yang datar, selanjutnya diamati tukak yang terbentuk (Gusdinar dkk., 2009). Pengamatan terhadap tukak yang terbentuk dengan pemberian skor berdasarkan metode Szabo dkk. (1985) yang dimodifikasi (Tabel 1). 
Tabel 1. Skoring keparahan tukak Szabo dkk. (1985) yang dimodifikasi

\begin{tabular}{lcc}
\hline \multicolumn{2}{l}{ Penampang lambung } & Skor \\
\hline Normal & & 0 \\
Hyperemia & Petechiae & 1 \\
Hemmorhage & 2 \\
& Ecchymoses & 3 \\
& Purpura & 4 \\
Erosi & & 5 \\
\hline
\end{tabular}

Keterangan: Hyperemia adalah kondisi pembuluh darah berdilatasi dan terisi butiran-butiran darah secara berlebihan. Erosi adalah terlepasnya epitel mukosa superfisial. Hemmorhage (perdarahan) adalah butir-butir darah keluar dari pembuluh darah dan tersebar diantara jaringan. Petechiae adalah bintik perdarahan ukuran 0,1-0,2 cm. Ecchymoses adalah bintik-bintik perdarahan ukuran 0,2 - 3,0 cm. Purpura adalah bintik perdarahan ukuran $>3 \mathrm{~cm}$ (Szabo dkk., 1985)

Rata-rata jumlah skor tiap kelompok perlakuan dinyatakan sebagai indeks tukak atau indeks tukak lambung, yang kemudian dibandingkan dengan kelompok kontrol. Kemampuan proteksi atau rasio proteksi suatu bahan terhadap ulcer dihitung dengan rumus seperti berikut:

$$
\% \text { Ratio Proteksi }=100 \%-\left[\frac{\mathrm{IU} \text { kelompok uji }}{\mathrm{IU} \text { kontrol } \text { ulcer }} \times 100 \%\right]
$$

(Saptarini dkk., 2011)

\section{IU: Indeks Ulcer}

\section{Pemeriksaan histopatologi}

Lambung dimasukkan dalam kain kasa, didehidrasi dan direndam dalam larutan etanol bertingkat yaitu $70 \%, 80 \%, 90 \%, 100 \%, 100 \%$ dan $100 \%$ masing-masing selama 60 menit pada suhu kamar. Proses selanjutnya dilakukan penjernihan (clearing) menggunakan xylol selama 15 menit pada suhu kamar sebanyak tiga kali. Setelah proses clearing dilakukan proses infiltrasi dengan parafin cair sebanyak 3 kali pemindahan masing-masing 60 menit dalam inkubator suhu $60^{\circ} \mathrm{C}$. Jaringan kemudian dibenamkan dalam parafin cair dan didinginkan dalam suhu kamar sehingga menjadi blok parafin.

Selanjutnya dilakukan proses embedding dan pemotongan dengan mikrotom arah horisontal dengan ketebalan $3 \mu$. Pengecatan toluidin blue dilakukan dengan prosedur sebagai berikut: parafin dihilangkan dengan xylol, kemudian dimasukkan dalam etanol $100 \%$, 95\% dan $70 \%$ masing-masing selama 5 menit, kemudian dimasukkan dalam aquades. Pengecatan dengan toluidin blue selama 40 - 60 menit dalam oven suhu $600^{\circ} \mathrm{C}$, kemudian dimasukan ke dalam etanol
70\%, 95\% dan 100\%. Setelah diberi Canada balsam ditutup dengan deck glass.

\section{Analisis data}

Analisis gambaran histopatologis lambung dengan melakukan pengamatan di bawah mikroskop. Analisis preparat irisan lambung dilakukan dengan mengamati perubahan spesifik yang terjadi pada lambung tersebut (Maslachah dkk., 2008).

\section{HASIL DAN PEMBAHASAN}

Berdasarkan pengamatan terhadap anatomi lambung mencit tidak terdapat adanya karakter yang menunjukkan tukak lambung seperti hyperemia, hemmorhage petechiae, hemmorhage ecchymoses, hemmorhage purpura, atau erosi (hilangnya jaringan dinding lambung). Lambung mencit pada perasan bengkuang $20 \%, 40 \%$ dan $60 \%$ tidak terdapat pendarahan dan tidak ada luka yang dilihat secara anatomi makroskopik. Umbi bengkuang diketahui mengandung senyawa adenin, kolin, saponin dan flavonoid (Catteau dkk., 2003). Flavonoid diketahui dapat berfungsi sebagai gastroprotektif melalui mekanisme kerja antiinflamasi dengan menghambat pembentukan netrofil/sitokin dalam saluran cerna (Alarcon dkk., 1995), ekspresi protein antioksidan yang memicu perbaikan jaringan melalui ekspresi berbagai faktor pertumbuhan (Kim dkk., 2004). Tanin memiliki ekspresi protein astringen, mengendapkan protein membran mukosa dan kulit. Tani (1976) dan Esaki dkk. (1986) menyatakan bahwa tanin menghambat sekresi lambung, memiliki kerja proteksi lokal pada mukosa lambung. Gambar anatomi lambung mencit dapat dilihat pada Gambar 1. 


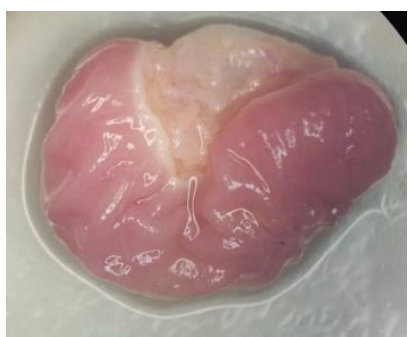

Normal

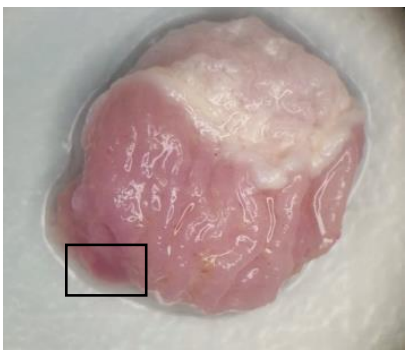

Bengkuang 20\%

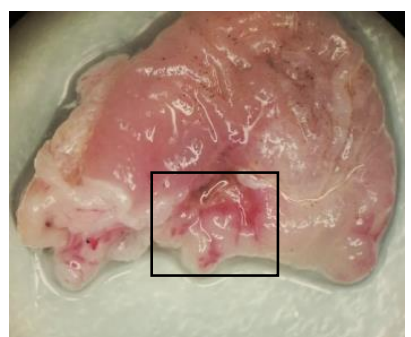

Etanol 96\%

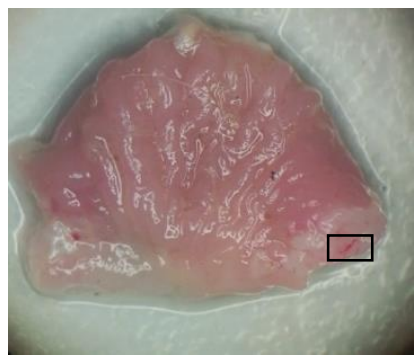

Bengkuang $40 \%$

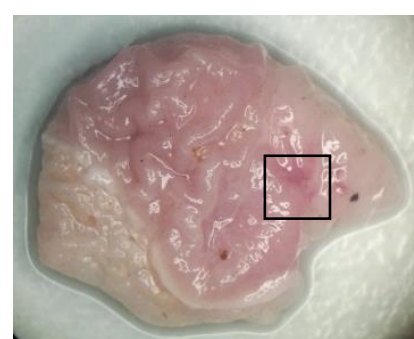

Sukralfat

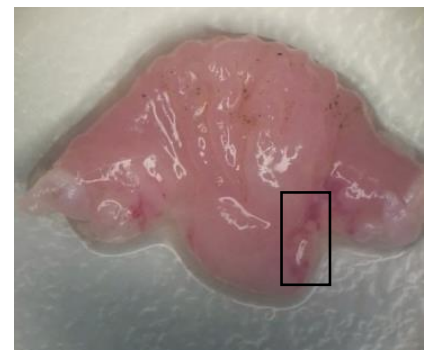

Bengkuang $60 \%$

Keterangan: $\square$ menunjukkan hyperemia

Gambar 1. Anatomi lambung mencit

Pengamatan tukak lambung dilakukan dengan memberikan skor terhadap setiap penampang lambung dengan menggunakan metode Szabo dkk. (1985) yang telah dimodifikasi. Untuk menghindari terjadinya subjektivitas pada hasil, maka pemberikan skoring dilakukan oleh 3 pengamat. Hasil pengamatan tukak lambung pada mencit dapat dilihat pada Tabel 2.

Setelah diperoleh nilai indeks tukak lambung selanjutnya dihitung nilai rasio proteksi. Hasil rata-rata rasio proteksi dapat dilihat pada Tabel 3 .

Tabel 2. Rerata indeks tukak lambung pada mencit yang diinduksi etanol $96 \%$

\begin{tabular}{ccc}
\hline Kelompok & Dosis $(\mathrm{g} / 100 \mathrm{~mL})$ & Rata-rata \\
\hline Normal & - & 0 \\
Kontrol Negatif & - & 3,89 \\
Perasan umbi & $20 \%$ & 0,56 \\
bengkuang & $40 \%$ & 0,22 \\
& $60 \%$ & 1,22 \\
Sukralfat & $0,1 \mathrm{~mL}$ & 1,11 \\
\hline
\end{tabular}

Tabel 3. Rasio proteksi pada mencit yang diinduksi etanol $96 \%$

\begin{tabular}{ccc}
\hline Kelompok & Dosis $(\mathrm{g} / 100 \mathrm{~mL})$ & Ratio Proteksi \\
\hline Normal & - & $100 \%$ \\
Perasan umbi & $20 \%$ & $85,60 \%$ \\
bengkuang & $40 \%$ & $94,34 \%$ \\
& $60 \%$ & $68,64 \%$ \\
Sukralfat & $0,1 \mathrm{~mL}$ & $71,47 \%$ \\
\hline
\end{tabular}

Indeks tukak lambung pada kelompok perasan umbi bengkuang dosis $20 \%$ menunjukkan nilai 0,56 dengan ratio proteksi $85,60 \%$, sedangkan pada kelompok perasan umbi bengkuang dosis $40 \%$ menghasilkan nilai 0,22 dengan ratio proteksi $94,34 \%$. Pada kelompok perasan umbi bengkuang $60 \%$ menunjukkan hasil indeks tukak 1,22 dengan ratio proteksi yang lebih rendah dibandingkan dosis $20 \%$ dan $40 \%$ yaitu $68,64 \%$. Pada kelompok pembanding yaitu sukralfat menunjukkan hasil indeks tukak 1,11 dengan ratio proteksi $71,47 \%$. Hasil ini lebih baik jika dibandingkan dengan kelompok dosis $60 \%$.

Dari hasil perhitungan rasio proteksi dengan menggunakan rumus oleh Saptarini dkk. (2011). Hasil rasio proteksi menunjukkan adanya peningkatan rasio proteksi dengan meningkatnya dosis perasan umbi bengkuang, akan tetapi pada dosis $60 \%$ terjadi penurunan ratio proteksi. Hal ini dimungkinkan karena adanya penurunan aktivitas senyawa pada dosis tertentu setelah mengalami efektivitas maksimal.

Berdasarkan pengamatan terhadap anatomi lambung mencit kelompok normal tidak terdapat adanya karakter yang menunjukkan tukak lambung seperti hyperemia, hemmorhage petechiae, hemmorhage ecchymoses, hemmorhage purpura atau erosi (hilangnya jaringan dinding lambung). Lambung mencit pada perasan bengkuang 20\%, $40 \%$ dan $60 \%$ tidak terdapat perdarahan dan tidak ada luka yang dilihat secara anatomi makroskopik, hanya saja masih terlihat beberapa hyperemia.

Pengamatan histopatologi lambung mencit juga dilakukan untuk menunjang hasil penelitian. Selain itu, 
pengamatan histopatologi juga bertujuan untuk melihat gambaran jaringan lambung dari kerusakan oleh senyawa penginduksi tukak lambung dan untuk melihat perbaikan jaringan lambung setelah pemberian perasan umbi bengkuang. Berikut adalah preparat histologi lambung mencit yang akan dianalisis setelah dilakukan pengamatan dengan menggunakan mikrokoskop. Hasil pengamatan histopatologi lambung mencit dapat dilihat pada Gambar 2.

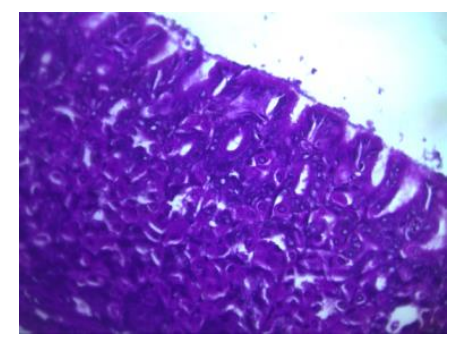

Normal

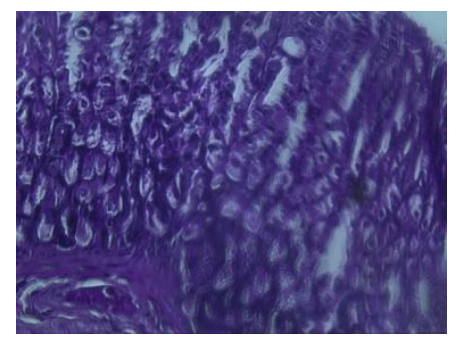

Bengkuang 20\%

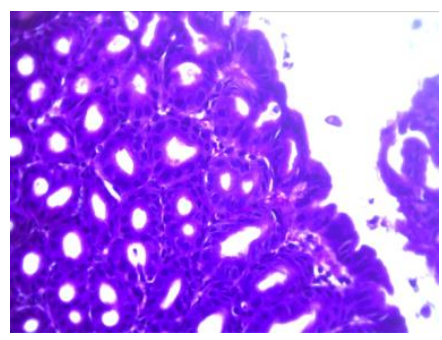

Etanol 96\%

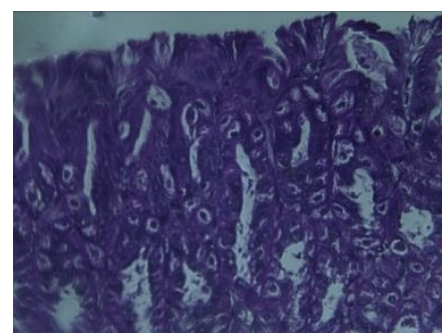

Bengkuang $40 \%$

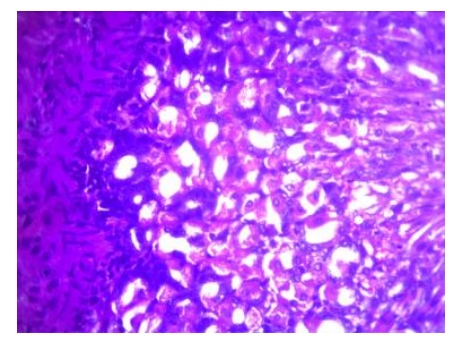

Sukralfat

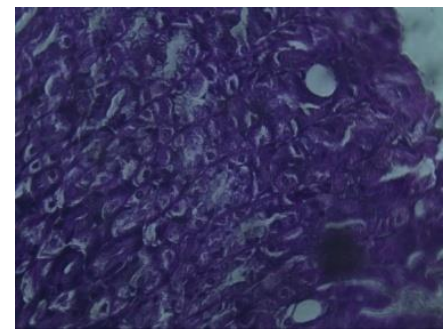

Bengkuang $40 \%$

Gambar 2. Gambaran histopatologi lambung mencit (perbesaran 10 x 40)

Dari hasil pengamatan histopatologi dapat terlihat adanya perbaikan jaringan lambung mencit pada pemberian air perasan bengkuang. Pada gambaran histopatologi lambung menunjukkan gambar yang hampir sama dengan histopatologi lambung normal.

\section{KESIMPULAN}

Pemberian perasan umbi bengkuang (Pachyrhizus erosus L.) dapat mencegah kerusakan lambung mencit yang disebabkan oleh induksi etanol.

\section{UCAPAN TERIMA KASIH}

Penulis mengucapkan terima kasih kepada pihak yang telah banyak membantu dalam penelitian ini. Ucapan terima kasih terutama penulis ucapkan kepada Lembaga Penelitian dan Pengabdian Masyarakat Universitas Bengkulu, atas kesempatan yang diberikan dalam melaksanakan Penelitian Pembinaan Universitas.

\section{DAFTAR PUSTAKA}

Masenchipz. (2008). Manfaat Bengkuang. http://www.masenchipz.com. Accessed: 10 Februari 2018.

Alarcon, D. L. L. A. C., Martin, M. J. \& Motilva, V. (1995). Gastroprotection Induced by Silymarin, the Hepatoprotective Principle of Silybum marianum in Ischemia-reperfusion Mucosal Injury: Role of Neutrophils. Planta Medica; 61; 116-119.

Avunduk, C. (2008). Manual of Gastroenterology: Diagnosis and Therapy 4th Edition. Boston: Tufts University Medical School.

Catteau, A., Roue, G., Yuste, V. I., Susin, S. A. \& Despres, P. (2003). Expression of Dengue ApoptoM Sequence Results in Disruption of Mitochondrial Potential and Caspase Activation. Biochimie; 85; 789-793.

Esaki, N., Kato, M., Takizawa, N., Morimoyo, S., Nonaka, G. \& Nishioca, I. (1986). Pharmacological Studies on Linderaeumbellate Ramus IV: Effects of Condensedtannin Related Compounds on Pepiticacitivity and Stressinduced Gastric Lesions in Mice.Planta Medica; 1 ; 34-38.

Feri. (2008). Bengkuang Berkhasiat sebagai Obat. http://feriweb.wordpress.com. Accessed: 10 Februari 2018.

Goodman, G. (2008). Farmakologi dan Toksikologi Etanol (In: Brunton, L. L., Parker, K. L., Blumenthal, D. K. \& Buxton, I. L. O, editor. Alih Bahasa: Sukandar, E. Y., Adnyana, I. K., Sigit, J. I., Sasongko, L. D. N. \& Anggadiredja, K). Jakarta: Penerbit Buku Kedokteran EGC. 
Gusdinar, T., Herowati, R., Kartasasmita, R. E. \& Adnyana, I. K. (2009). Synthesis and Gastric Ulcer Protective Activity of Chlorinated Quercetin. Indonesian Journal of Pharmacy; 20; 163-169.

Kim, S. C., Byun, S. H. \& Yang, C. H. (2004). Cytoprotective Effects of Glycyrrhizae Radix Extract and Its Active Component Liquiritigenin against Cadmium-induced Toxicity (Effects on Bad Translocation and Cytochrome C-mediated PARP cleavage). Toxicology; 197; 239-251.

Kumar, V., Cotran, R. S. \& Robbins, S. L. (2007). Rongga Mulut dan Saluran Gastrointestinal. In: Crawford, J. M \& Kumar, V., editor. Jakarta: Penerbit Buku Kedokteran EGC.

Lukitaningsih, E. (2010). Fitoestrogen: Senyawa Alami yang Aman sebagai Pengganti Hormon Estrogen pada Wanita. http://farmasi.ugm.ac.id. Accessed: 5 September 2013.

Maslachah, L., Sugihartini, R. \& Ankestri, H. (2008). Desscription of White Rat (Rattus norvegicus) Intestine that was Given Juice of Noni (Morinda citrifolia) and High Fatty Diet. Veterinaria Medika; 1; 103-108

Mentang, D. R., Loho, L. L. \& Lintong, M. P. (2016). Gambaran Histopatologik Lambung Tikus
Wistar (Rattus norvegicus) yang Diberi Perasan Umbi Bengkuang (Pachyrhizus erosus (L) Urban) setelah Induksi Aspirin. Jurnal eBiomedik; 4; 218-223.

Pan, J., He, S., Xu, H., Zhan, X., Yang, X., Xiao, H. M. Shi, H. X. \& Ren, J. L. (2008). Oxidative Stress Disturbs Energy Metabolism of Mitochondria in Etanol-induced Gastric Mucosa Injury. World Journal of Gastroenterology; 14; 5857-5867.

Saptarini, N. M., Suryasaputra, D. \& Saepulhak, A. M. (2011). Analisis Rasio Proteksi Antiulser Sari Buah Pepino (Solanum muricaum Aiton) menggunakan Tikus sebagai Model Hewan Coba. Majalah Obat Tradisional; 16; 75-80.

Szabo, S., Trier, J. S., Brown, A., Schnoor, J., Homan, H. D. \& Bradford, J. C. (1985). A Quantitative Method for Assesing The Extent of Experimental Gastric Erosions and Ulcers. Journal of Pharmacology and Toxicological Methods; 13; 59-66.

Tani, S. (1976). Effect of Tannic Acid and Tannic Acid Atarch on the Experimental Gastric Ulcer in Rats. Journal of Pharmacy Society of Japan; 96; 648-652. 